\title{
STRATEGI KOMUNIKASI PENINGKATAN PRAKTEK IMUNISASI DIFTERI PADA IBU BALITA DI PUSKESMAS CIJEDIL, DINAS KESEHATAN KABUPATEN CIANJUR
}

\author{
Juhamad $^{1)}$, Tri Krianto ${ }^{2 *}$ \\ ${ }^{I}$ Magister Kesehatan Masyarakat, Fakultas Kesehatan Masyarakat Universitas Indonesia \\ 2)* Departemen Pendidikan Kesehatan dan Ilmu Perilaku Fakultas Kesehatan Masyarakat Universitas \\ *tkarjoso@gmail.com
}

\begin{abstract}
ABSTRAK
Difteri merupakan salah satu penyakit menular dan sering menimbulkan kejadian luar biasa (KLB) di beberapa wilayah. Difteri merupakan penyakit yang sering menyebabkan kematian, karena racun yang dihasilkan oleh bakteri Corynebacterium diphterie. Berdasarkan masalah yang terjadi di Kabupaten Cianjur mulai pada tahun 2013 ditemukan penderita difteri sebanyak 6 kasus dan 1 orang meninggal dengan Case Fatality Rate sebesar 17\%. Sedangkan pada tahun 2015 ditemukan penderita difteri sebanyak 3 kasus. Kemudian pada tahun 2017 terdapat 15 pasien difteri yang ditangani RSUD Cianjur beberapa diantaranya dirujuk ke Rumah Sakit Hasan Sadikin Bandung karena jumlah penderita meningkat sedangkan ruang isolasi terbatas. Salah satu daerah yang terjadi KLB yaitu tepatnya di wilayah kerja Puskesmas Cijedil. Data vaksinasi yang di dapat di Puskesmas Cijedil yaitu berjumlah 86 bayi laki-laki dan 87 bayi perempuan sehingga jumlahnya 173 bayi laki- laki dan perempuan, sedangkan yang sudah mendapatkn vaksinasi DPT 1 dan HB1 untuk kategori bayi laki laki berjumlah 71 atau 82,6\% dan kategori bayi perempuan berjumlah 84 atau 96,6\% yang sudah mendapatkan imunisasi DPT1 dan HB1. Penelitian ini mengunakan desain metode kualitatif yang mempelajari tentang peningkatan praktek imunisasi difteri pada ibu balita di Puskesmas Cijedil,Dinas Kesehatan kabupaten cianjur mulai bulan Februari sampai Maret 2019 dan pengumpulan data dilakukan dengan wawancara dengan ibu balita dan petugas kesehatan, kader posyandu. Hasil penelitian menunjukan bahwa adanya peningkatan praktek imunisasi pada ibu balita di Desa Cijedil tahun 2019. dari hasil wawancara mendalam menggunakan kuesioner di dapatkan bahwa ibu balita terkait pengerahuan ibu balita tentang imunisasi difteri dan pencegahan difteri menunjukan adanya peningkatan praktek imunisasi difteri. Disarankan kepada petugas Petugas promosi kesehatan Dinas Kesehaan Cianjur agar lebih ditingkatkan lagi kunjungan imunisasi setiap satu bulan sekali agar peserta imunisasi difteri dapat mengerti betul tentang pencegahan penyakit difteri.
\end{abstract}

Kata kunci: Difteri, Strategi Komunikasi Praktek Imunisasi, Kabupaten Cianjur

\section{PENDAHULUAN}

Difteri merupakan salah satu penyakit menular dan sering menimbulkan kejadian luar biasa (KLB) di beberapa wilayah. Difteri merupakan penyakit yang sering menyebabkan kematian, karena racun yang dihasilkan oleh bakteri Corynebacterium diphteria. Bakteri membuat toksin apabila bakteri terinfeksi oleh coryne bacteriophage yang mengandung diphteria Ia toxin gene tox. Semua umur dapat terkena difteri tetapi kebanyakan menyerang anak-anak yang tidak dimunisasi (Nelson, 2004)

Menurut World Health Organization (WHO), tercatat ada 7.097 kasus difteri yang dilaporkan di seluruh dunia pada tahun 2016. Di antara angka tersebut, Indonesia turut menyumbang 342 kasus. Sejak tahun 2011, kejadian luar biasa (KLB) untuk kasus difteri menjadi masalah di Indonesia. Tercatat 3.353 kasus difteri dilaporkan dari tahun 2011 sampai dengan tahun 2016 dan angka ini menempatkan Indonesia menjadi urutan ke-2 setelah India dengan jumlah kasus difteri terbanyak. Dari 3.353 orang yang menderita difteri, dan 110 di antaranya meninggal dunia. Hampir 90\% dari orang yang terinfeksi, tidak memiliki riwayat imunisasi difteri yang lengkap. (WHO, 2016)

Difteri termasuk salah satu penyakit yang dapat dicegah dengan imunisasi dan imunisasi terhadap difteri termasuk ke dalam program imunisasi wajib pemerintah Indonesia. Imunisasi difteri yang dikombinasikan dengan pertusis (batuk rejan) dan tetanus ini disebut dengan imunisasi DPT. Sebelum usia 1 tahun, anak 
diwajibkan mendapat 3 kali imunisasi DPT. Cakupan anak-anak yang mendapat imunisasi DPT sampai dengan 3 kali di Indonesia, pada tahun 2016, sebesar 84\%. Jumlahnya menurun jika dibandingkan dengan cakupan DPT yang pertama, yaitu 90\%. (WHO, 2016)

Menurut Ketua Ikatan Dokter Anak Indonesia (IDAI)), serta adanya orang dewasa yang terjangkit difteri, bahkan ada penderita usia 45 tahun yang meninggal, padahal sudah mendapat vaksinasi dasar DPT secara lengkap, membuat penulis bertanya-tanya, serta memberi usulan kepada Kementrian Kesehatan RI, yaitu Ciri khas penyakit ini adalah terbentuknya lapisan tebal abu-abu (pseudomembrane) yang menutupi bagian belakang tenggorokan Anda, di daerah tonsil (amandel) dan nasofaring (daerah antara tenggorokan dan rongga hidung belakang). Lapisan tebal ini dapat menutup jalan napas Anda, menyebabkan hambatan aliran udara oksigen. (IDAI, 2017)

Pada tahun 2014, jumlah kasus difteri di Indonesia menempati urutan ketiga terbanyak di dunia setelah India dan Nepal dengan 421 kasus hingga bulan November. Jumlah Kasus penyakit Difteri di Indonesia mengalami peningkatan dari tahun 2010 hingga tahun 2012, dan mengalami penurunan pada tahun 2013 dan 2014. Pada tahun 2010 kasus difteri di Indonesia adalah 432 kasus, naik menjadi 806 kaus pada tahun 2011, dan naik menjadi 1192 kasus pada tahun 2012. Pada tahun 2013 jumlah kasus turun menjadi 475 dan hingga November 2014 turun menjadi 421 kasus. (WHO, 2014)

Pola resistensi antibiotik terhadap bakteri difteri menunjukkan kepekaan antibiotik penicillin terhadap difteri sebesar 84 persen dan kepekaan eritromisin sebesar 91,2 persen. Kepekaan antibiotik menunjukkan kemampuan daya bunuh antibiotik terhadap bakteri. Saat ini penisilin dan eritromisin adalah antibiotik pilihan untuk mengobati penyakit difteri. Tingkat kepekaan antibiotik tersebut menurun dibanding hasil penelitian Robert C. Penelitian Rockhill di Rumah Sakit Cipto Mangunkusumo (RSCM) Jakarta pada 1982 yang menunjukkan antibiotik ampisilin, yang merupakan golongan penisilin, dan antibiotik eritromisin masih 100 persen sensitif terhadap difteri. Indonesia perlu kajian lanjut dan mempertimbangkan tinjauan tata laksana pengobatan difteri, yang perlu diwaspadai adalah kecenderungan jumlah kasus penyakit ini meningkat sejak 2007 (183 kasus) dan puncaknya pada 2012 (1.192 kasus). Setelah itu menurun tapi angkanya masih ratusan kasus. Jumlah kasus difteri Indonesia dari tahun ke tahun. (Riskesdas, 2013).

Berdasarkan hasil penelitian terdahulu yang dilakukan oleh cut safira ulfah dari Universitas Syiah Kuala, tentang strategi komunikasi difteri di dinas kesehatan kota banda aceh tahun 2018 ,maka dapat dilakukan strategi komunikasi dengan cara penanggulangan penyakit difteri melalui empat bentuk strategi antara lain :

a) Promotif (promosi)

- Penyuluhan atau sosialisasi

Salah satu bentuk melakukan sosialisasi kepada masyarakat tentang bahaya penyakit difteri dan cara penanggulangan penyakit difteri oleh puskesmas setempat.

- Pembagian leaflet, berupa selembaran kertas yang yang berisi tulisan dengan kalimat-kalimat yang singkat, padat, mudah dimengerti dan gambar-gambar yang cukup sederhana. Leaflet disini diharkan dapat memberikan keterangan singkat tentang masalah difteri misalnya tentang cara pencegahan,menjaga lingkungan sekitar rumah dan sebagainya. 
- Pemasangan baliho yang didirikan dipinggir jalan/ disamping lampu merah dengan tujuan agar masyarakat yang melintasi jalan berhenti agar bisa membaca akan sadar pentingnya waspada terhadap Bahasa penyakit difteri.

b) Preventif (pencegahan) dengan cara melakukan pemutusan penularan, menurunkan jumlah kasus difteri dan mencegah agar penyakit difteri tidak meluas, kemudian melakukan 1 putaran imunisasi difteri seluas kecamatan dengan range sampai umur kasus, melakukan vaksin DPT-HB Hib untuk usia 1 tahun sampai < 5 tahun, DT untuk usia 5 tahun sampai kurang dari 7 tahun dan TD untuk usia diatas 7 tahun.

c) Kuratif (pengobatan) dengan cara melakukan upaya seperti dokter melakukan suntikan antitoksin untuk melawan racun yang dihasilkan oleh difteri.

d) Rehabilitatif (penyembuhan) dengan cara memberikan pengetahuan tentang pentingnya penyakit difteri, bahaya penyakit ini dan cara penanggulangannya.

Dengan demikian kasus yang terjadi di dinas kesehatan kota banda aceh khususnya penyakit difteri dapat teratasi.

Penyakit difteri masih ditemukan di Kabupaten Cianjur pada tahun 2013 ditemukan penderita difteri sebanyak 6 kasus dan meninggal 1 orang demikian Case Fatality Rate sebesar 17\%. 6 kasus tersebut terjadi di wilayah puskesmas Cibeber, Cibaregbeg, Ciranjang, Cipendawa, dan Campaka. Paling banyak terjadi di wilayah Puskesmas Cipendawa sebanyak 2 kasus dan 1 orang meninggal. (Profil Kesehatan Kabupaten Cianjur, 2013) Penyakit difteri masih ditemukan di Kabupaten Cianjur pada tahun 2015 ditemukan penderita difteri sebanyak 3 kasus yaitu di wilayah puskesmas Cibeber, Cipandawa dan Cipeuyeum. (Profil Kesehatan Kabupaten Cianjur, 2015)

Di Kabupaten Cianjur awal tahun 2017 dan awal 2018 terdapat 15 pasien difteri yang ditangani RSUD Cianjur beberapa diantaranya dirujuk ke Rumah Sakit Hasan Sadikin Bandung karena jumlah penderita meningkat sedangkan ruang isolasi terbatas. Salah satu daerah yang terjadi KLB yaitu tepatnya di wilayah kerja Puskesmas Cijedil. Kejadian ini tentu menjadi perhatian banyak pihak sehingga peneliti merasa penting untuk melakukan penelitian didaerah tersebut. (Profil Kesehatan Kabupaten Cianjur 2017).

Strategi komunikasi adalah suatu rancangan yang dibuat untuk mengubah tingkah laku manusia dalam skala yang lebih besar melalui transfer ide-ide baru. Hal senada diungkapkan Effendy (2003:300) bahwa dalam hakikatnya strategi adalah merencanakan dan managemen untuk mencapai suatu tujuan. Namun untuk mencapai suatu tujuan tersebut, strategi tidak berfungsi sebagai peta jalan saja yang menunjukan arah, tetapi harus menunjukan taktik operasionalnya. Dalam menyusun strategi komunikasi dalam bidang kesehatan, khususnya masalah imunisasi difteri (Humaidi,2015).

Strategi komunikasi adalah tahapan konkret dalam rangkaian aktivitas komunikasi yang berbasis pada satuan teknis bagi mengimplementasikan tujuan komunikasi, adapun teknik adalah untuk komunikasi berdasarkan strategi yang diterapkan sebelumnuya,rencana yang meliputi metode ,teknik dan tata hubungan funsional dalam melakukan tujuan komunikasi kesehatan (Yusup Zainal Abidin,2015).

Dalam hal ini akan dititik beratkan pada strategi komunikasi imunisasi difteri meliputi langkah-langkah sebagai berikut: 
1. Tersampaikannya informasi imunisasi difteri kepada ibu balita, imunisasi tersebut sangatlah penting agar tidak terjadi yang namanya penularan penyakit difteri.

2. Tersedianya vaksin imunisasi DPT 1 dan HB1 secara merata agar di setiap wilayah khususnya wilayah Puskesmas Cijedil dapat memaksimalkan pemberian imunissi kepada balita yang belum di imunisasi.

3. Adanya kerjasama antar lintas sektor misalnya Kepada Desa Ketua RT/RW dan para Kader imunisasi yang di tunjuk langsung oleh petugas kesehatan setempat

4. Pemberian pemahaman mendalam kepada ibu balita terkait pemberikan imunisasi difteri (misalnya manfaat imunisasi difteri dan bahaya penyakit difteri apabila balita tidak di imunisasi)

Teori pemrosesan informasi McGuire (1989) memberikan sebuah pandangan yang bagus tentang proses perubahan sikap, mengingatkan bahwa ia melibatkan sejumlah komponen. Sikap pada dasarnya adalah cara pandang kita terhadap sesuatu. Sikap memiliki tiga komponen, yakni komponen afektif, komponen kognitif dan komponen perilaku. Komponen afektif berisi perasaan-perasaan tertentu terhadap objek sikap. Komponen kognitif berisi keyakinan terhadap objek sikap. Sedangkan komponen perilaku berisi perilaku yang disengaja terhadap objek sikap.

M. De Mey (1977) mengatakan bahwa kognisi seseorang merupakan faktor yang sangat penting dalam menerima dan mengelola informasi. Setiap pemrosesan informasi diperantarai oleh pengkategorian dan pengenaan konsep. Kategori dan konsep ini adalah sebuah tiruan/model tentang dunia sekeliling. Proses informasi menentukan pembentukan makna pada seseorang dam merupakan konstruksi dari sebuah perubahan sikap.

Keefektifan dari komunikasi yang diberikan akan bergantung pada input dan karakteristik yang berbeda, begitupun dengan tipe output yang diinginkan. Faktor output menggambarkan perubahan spesifik dari penerima pesan yang diharapkan dari keterpaparan informasi terhadap perubahan perilaku jangka panjang. Implikasi dari perubahan diasumsikan bahwa perubahan pengetahuan adalah syarat utama untuk perubahan perilaku yang merupakan poin penting sebagai kondisi awal seseorang akan mengambil sebuah keputusan dan mengubah perilaku (Elder, 1994).

\section{METODE PENELITIAN}

\section{Ethical Considerant (Aspek Etika Penelitian)}

Penelitian ini sudah dikaji etik oleh komite etik Fakultas Kesehatan Masyarakat Universitas Indonesia, dan penulitasn inform consent untuk semua informan untuk wawancara mendalam sebelum dilakukan pengumpulan data

\section{Study Design (Desain Penelitian)}

Penelitian ini merupakan penelitian di bidang Ilmu Kesehatan Masyarakat dengan metode penelitian yang digunakan yaitu metode penelitian kualitatif dengan mengunakan triangulasi data

\section{Study Populasi (Sampel Penelitian)}

1. informan yang dipilih berjumlah 20 informan terdiri dari petugas kesehatan, kader posyandu dan ibu balita dan harus memenuhi kategori-kategori yang berkaitan dengan penelitian. Adapun kriteria informan dalam penelitian ini, yaitu: 
a. Ibu Balita di Wilayah Puskesmas Cijedil yang Terkena KLB Tahun 2017-2018

Sebagai Informan yang akan diteliti dengan karakteristik Ibu Balita yang berusia usia 20 - 40 tahun di wilayah Puskesmas Cijedil yang terkena KLB pada tahun 2017 sampai 2018.

\section{Pengumpulan Data}

Data yang dikumpulkan berupa data primer dan bersifat tekstual. Sumber data dalam penelitian ini adalah Ibu balita di wilayah kerja Puskesmas Cijedil yang terkena KLB pada tahun 2017 sampai 2018. Penetapan informan tersebut berdasarkan asas kesesuaian dan kecukupan.

Tabel 1.

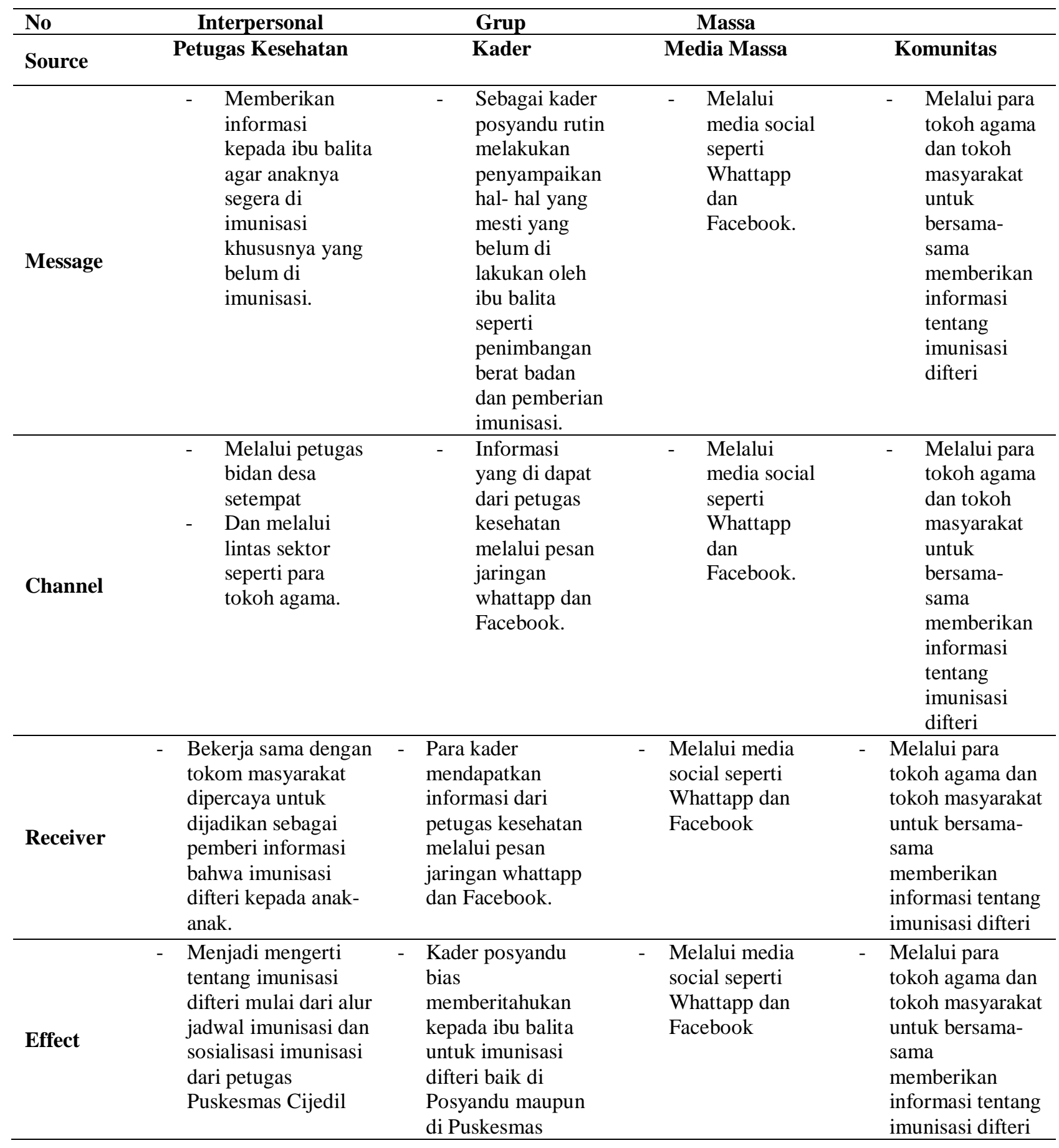




\begin{tabular}{|c|c|c|c|c|c|}
\hline Feedback & 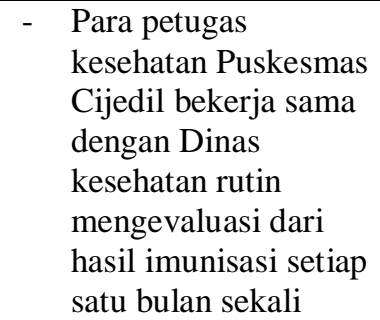 & $\begin{array}{l}\text { Kader Posyandu } \\
\text { tahu bagaimana } \\
\text { mengenal satu } \\
\text { perstu ibu balita } \\
\text { yang sudah } \\
\text { mendapatkan } \\
\text { informasi terkait } \\
\text { imunisasi difteri. }\end{array}$ & $\begin{array}{l}\text { - Melalui media } \\
\text { social seperti } \\
\text { Whattapp dan } \\
\text { Facebook }\end{array}$ & - & $\begin{array}{l}\text { Melalui para } \\
\text { tokoh agama dan } \\
\text { tokoh masyarakat } \\
\text { untuk bersama- } \\
\text { sama } \\
\text { memberikan } \\
\text { informasi tentang } \\
\text { imunisasi difteri }\end{array}$ \\
\hline
\end{tabular}

\section{HASIL PENELITIAN}

Dari hasil penelitian menunjukan bahwa strategi komunikasi yang dilakukan untuk peningkatan praktek imunisasi difteri pada ibu balita ada 3 pendekatan komunikasi yaitu aspek interpersonal, aspek grup dan aspek media massa

1. Aspek interpersonal yaitu melibatkan petugas kesehatan

2. Aspek grup yaitu melibatkan para kader posyandu

3. Aspek Massa yaitu melibatkan media massa dan komunitas

Tabel 1 Menunjukan adanya perubahan pengetahuan mengenai imunisasi difteri yang dilakukan oleh ibu balita di Desa Cijedil wilayah Puskesmas Cijedil, Dinas Kesehatan Kabupaten Cianjur tahun 2019

\section{PEMBAHASAN HASIL PENELITIAN}

\section{Menggali Pengetahuan ibu balita tentang imunisasi difteri pada balita di Puskesmas Cijedil}

Dari hasil yang di dapat bahwa ibu balita mendapatkan mengetahuan dari petugas kesehatan yang selalu memberikan informasi terkait imunisasi difteri, kemudian melalui media social seperti WA, Facebook dan buku panduan imunisasi difteri.

Menurut Lawrence Green dalam Notoatmodjo (2000) pengetahuan merupakan salah satu factor yang dapat memudahkan dalam mempengaruhi seseorang berperilaku positif atau negarif dalam kehidupannya.Tingkat pengetahuan ibu lebih tinggi akan memberikan respon lebih baik terhadap program kesehatan (Notoatmodjo,1993).

Pengetahuan ibu bisa oleh karena rasa takut sesuatu yang mungkin terjadi, sehingga rasa takut ini akan menyebabkan seseorang menjadi lebih banyak ingin tahu mengenai penyakit tersebut (Notoatmodjo,1993)

Dari hasil wawancara mendalam di dapatkan informasi ibu balita.

"saban hiji sasih kalintang sok diayakeun posyandu di puskesmas cijedil khususna imunisasi difteri sarta panimbangan abot awak balita anu di pigaw e sapertos bidan jeung kader posyandu desa cijedil"(Ibu balita A) "urang salaku patugas kesehatan sarta para kader posyandu sok nginformasikeun patali jadwal imunisasi sarta mikeun materi ngeunaan bahya panyakit ka indung balita anu aya di desa cijedil (Petugas Kesehatan)

Terjemahan ke Bahasa Indonesia hasil wawancara mendalam

"setiap satu bulan sekali selalu diadakan posyandu khususnya imunisasi difteri dan penimbangan berat badan balita (ibu balita A)

"kami selaku petugas kesehatan dan para kader selalu menginformasikan terkait jadwal imunisasi dan memberikan materi tentang bahaya penyakit difteri kepada ibu balita didesa cijedil”(Petugas Kesehatan). 
Menggali Pengetahuan ibu balita tentang cara pencegahan penykit difteri pada balita di Puskesmas Cijedil

Setelah diberikan pemahaman berupa materi tentang imunisasi difteri ibu balita sedikit demi sedikit mengerti akan cara pencegahan dini penyakit difteri di desa cijedil, Menurut Lawrence Green dalam Notoatmodjo (2000) pengetahuan merupakan salah satu factor yang dapat memudahkan dalam mempengaruhi seseorang berperilaku positif atau negarif dalam kehidupannya. Tingkat pengetahuan ibu lebih tinggi akan memberikan respon lebih baik terhadap program kesehatan (Notoatmodjo,1993).

Pengetahuan ibu bisa oleh karena rasa takut sesuatu yang mungkin terjadi, sehingga rasa takut ini akan menyebabkan seseorang menjadi lebih banyak ingin tahu mengenai penyakit tersebut (Notoatmodjo,1993)

Dari hasil wawancara mendalam di dapatkan informasi ibu balita. "saban hiji sasih kalintang sok diayakeun posyandu di puskesmas cijedil khususna imunisasi difteri sarta panimbangan abot awak balita anu di pigawe sapertos bidan jeung kader posyandu desa cijedil"(Ibu balita A)

"urang salaku patugas kesehatan sarta para kader posyandu sok nginformasikeun patali jadwal imunisasi sarta mikeun materi ngeunaan bahya panyakit ka indung balita anu aya di desa cijedil (Petugas Kesehatan)

Terjemahan ke Bahasa Indonesia hasil wawancara mendalam "setiap satu bulan sekali selalu diadakan posyandu khususnya imunisasi difteri dan penimbangan berat badan balita (ibu balita A) "kami selaku petugas kesehatan dan para kader selalu menginformasikan terkait jadwal imunisasi dan memberikan materi tentang bahaya penyakit difteri kepada ibu balita didesa cijedil"(Petugas Kesehatan)

\section{Menggali Pola Strategi Komunikasi ibu balita tentang imunisasi difteri pada balita di Puskesmas Cijedil}

Adapun strategi komunikasi imunisasi tentang peningkatan praktek imunisasi difteri antara lain:

1. Media sosial seperti:

- Facebook

- Whatsapp dll

2. Kerja sama lintas sektor

- Melibatkan tokoh agama atau orang berpegnaruh di wilayah tersebut

- Melibatkan tokoh masyarakat

- LSM yang bergerak di bidang kesehatan

3. Petugas kesehatan

- Ibu bidan desa

- $\quad$ Ibu kader posyandu

Ketiga cara ini membantu mengali pola strategi komunikasi terhadap ibu balita sehingga ibu balita mau mengimunisasikan anaknya ke puskesmas atau ke posyandu.

Adapun hasil dari wawancara mendalam terkait strategi komunikasi kepada ibu balita melalui kerja sama petugas kesehatan dan para kader posyandu Puskesmas Cijedil “urang salaku indung balita sok meunangkeun informasi yaktos kahiji melalui SMS,Telepon atawa talata WA ku kituna urang salaku indung balita teu kantos tuh teu tiasa informasi ngeunaan imunisasi difteri”"(Ibu Balita B) "Urang salaku petugas kesehatan sarta para kader posyandu desa cijedil bersinergi ku lintas sector kanggo menginformasikeun patali imunisasi difteri sarta 
bahaya difteri lamun henteu di imunisasi difteri"(Petugas Kesehatan B) Terjemahan dalam Bahasa Indonesia dari hasil wawancara mendalam "kami selaku ibu balita selalu mendapatkan informasi yaitu pertama memalui sms,tlpn maupun pesan WA sehingga kita selaku ibu balita engga pernah tuh sampe ga dapat informasi tentang imunisasi difteri"(Ibu Balita B) "kami para Nakes dan para kader bersinergi oleh lintas sector untuk menginformasikan terkait imunisasi difteri dan bahaya difteri jika tidak imunisasi difteri"'(Petugas Kader B)

\section{KESIMPULAN}

Dari hasil wawancara mendalam menggunakan uji kuesioner di dapatkan bahwa ibu balita terkait pengetahuan sikap dan perilaku ibu balita tentang imunisasi difteri dan pencegahan penyakit difteri menunjukan adanya peningkatan praktek imunisasi difteri yang dilakukan informan ibu balita untuk mau mengimunisasikan anaknya; Dari data evaluasi puskesmas cijedil pada tahun 2018 cakupan imunisasi sudah mencapai angka UCI (Universal Child on Imunization) yaitu $>80 \%$ artinya sudah hampir merata dilakukan imunisasi difteri di desa Cijedil; Masih terdapat pengaruh pandangan keagamaan yang kuat yang mengharamkan diberikannya imunisasi difteri, hal ini menjadi tantangan tersendiri bagi petugas kesehatan dan kader untuk melakukan kerjasama lintas sektor terutama terhadap kalangan islam yang memiliki pandangan konservatif.

Penelitian ini ditunjukan untuk petugas promkes Dinas Kesehatan Kabupaten Cianjur untuk dilakukan tindak lanjut mengenai strategi komunikasi peningkatan imunisasi difteri pada ibu balita agar setiap tahun ada peningkatan kesadaran,kepedulian dan pengetahuan para ibu balita untuk mengimunisasikan anaknya.

\section{KETERBATASAN PENELITIAN}

Keterbatasan penelitian di Puskesmas Cijedil diantaranya ada informan yang tidak mau di wawancarai karena dengan alasan tertentu seperti adanya informan yang memiliki pandangan bahwa imunisasi itu haram dan dapat mengakibatkan anak sakit, sehingga peneliti kurang mengetahui lebih dalam informasi terkait imunisasi difteri.

Keterbatasan Bahasa yang digunakan informan lebih banyak menggunakan basa sunda menjadi sedikit kendala, namun dapat diatasi dengan bantuan kader yang membantu dalam menjelaskan pertanyaan peneliti dan jawaban yang mendalam

\section{REFERENSI}

1. Anwar,A (1984),Strategi Komunikasi Suatu Pengantar Ringkas, Bandung:Armico hal 59

2. Cangara, H. (2013). Perencanaan dan Strategi Komunikasi. Jakarta : Rajawali Pers

3. Effendi ( 1998). Dalam bukunya yang berjudul Ilmu,Teori dan Filsapat Komunikasi, Bandung :

4. Effendi. O. (2003). Dalam bukunya yang berjudul Ilmu,Teori dan Filsapat Komunikasi, Bandung : Citra Aditya Bakti

5. Effendi. O. (2005). Ilmu komunikasi teori dan praktek. ( Bandung: Remaja Rosda Karya.

6. Effendi. O. (2009). Dalam bukunya yang berjudul Ilmu,Teori dan Filsapat Komunikasi, Bandung : Citra Aditya Bakti

7. Febril,A.M (2018) Cianjur Tetapkan kejadian luar biasa difteri ,Jabar .tribunews.com

8. http://jabar.tribunnews.com/2018/01/22/pemkab-cianjur-tetapkan-kejadian-luar-biasa-difteri-ribuanwarga-di-dua-kecamatan-akan-divaksin?page=2 diakses28November 2018. 
9. Febril, A.M (2018). Pemkab Cianjur Tetapkan Kejadian Luar Biasa Difteri, Ribuan Warga di Dua Kecamatan Akan Divaksin, http://jabar.tribunnews.com/2018/01/22/pemkab-cianjur-tetapkan-kejadian-luar-biasa-difteriribuan-warga-di-dua-kecamatan-akan-divaksin?page $=1$

10. Graeff, et all. Komunikasi untuk Kesehatan dan Perubahan Perilaku. Gadjah Mada University Press. Anggota IKAPI. 1996.

11. Hadi, Ella Dkk. Aplikasi Penelitian Kualitatif dalam Pemantauan dan Evaluasi Progra Kesehatan. Fakultas Kesehatan Masyarakat Universitas Indonesia bekerjasama dengan Pusat Data Kesehatan Departemen Kesehatan RI. 1998.

12. Handayani,S ( 2012 ). Deteksi Kuman Difteri.

13. Humaidi (2015) Teori komunikasi dan strategi komunikasi,(Malang:UMM Press,6.

14. Ikatan Dokter Anak Indonesia ( IDAI ), 2017 Jadwal imunisasi 2017 ( daring): 18 Desember 2017

15. Kartono, B ( 2007 ) hubungan lingkungan rumah dengan Kejadian Difteri pada kejadian luar biasa ( KLB ) Difteri di Kabupaten Tasikmalaya tahun 2005- 2006 dan di Kabupaten Garut pada bulan januari tahun 2007. Tesis Program Magister Program Ilmu Kesehatan Masyarakat Universitas Indonesia, Jakarta .

16. Kusuma SL. ( 2012 ) Faktor yang berhubungan dengan kejadian difteri,Tesis. Jakarta : Program Pascasarjana Fakultas Kesehatan Masyarakat Universitas Indonesia

17. Kemenkes (2017) Cakupan data imunisasi difteri .

18. https://sains.kompas.com/read/2017/12/07/080900823/kemenkes--difteri-tahun-ni-luar-biasa diunduh jam 16.11 wib

19. Liliweri, A. (2013). Dasar-dasar Komunikasi Kesehatan. Yogyakarta : Pustaka Pelajar

20. Littlejohn dan Foss (2009) dalam bukunya Encyclopedia of Communication Theory.

21. Maulana, H. (2009). Promosi Kesehatan. Jakarta : Penerbit Buku Kedokteran ECG

22. https://pakarkomunikasi.com/teori-komunikasi-massa diunduh jam 16.05 wib

23. http://www.managementstudyguide.com/berlo-model-of-communication.htm

24. Nelson .( 2006 ) Texbook of Pediatrik ( Philadelphia) : Saunders.

25. Nugraha IK,detik .com, 18 Desember 2017,17.59 WIB .IDAI : KLB Difteri di Indonesia paling tinggi di dunia (daring), 19 Desember 2017

26. Notoatmodjo,S,et al.,1993. Pendidikan Promosi dan Perilaku Kesehatan, Penerbit Andi Ofset, Yogyakarta.

27. Notoatmodjo,S,et al.,2000. Pendidikan Promosi dan Perilaku Kesehatan, Universitas Indonesia,FKM, Depok.

28. Permenkes RI, No 12 Tahun 2017 Tentang Penyelenggaraan Imunisasi. 